\title{
Development Design of Ecological - Contextual based Learning for Prosocial (ECOPS) in Social Studies Subject in Junior High School in Cimahi
}

\author{
Lussy Anggraeni ${ }^{1,}$ Bunyamin Maftuh ${ }^{2}$, Nana Supriatna ${ }^{3}$, Mamat Ruhimat ${ }^{4}$ \\ \{misslussy.anggraeni@gmail.com ${ }^{1}, \underline{\text { bunyaminmaftuh@upi.edu }}^{2},{\underline{\text { nanasup@ } @ \text { upi.edu }^{3}}}^{3}$ \\ mamatruhimat@upi.edu ${ }^{4}$ \} \\ Universitas Pendidikan Indonesia
}

\begin{abstract}
The currently occurring environmental problems are essentially consequences of individuals' disregard of their environment. Through social studies contextualizing ecological issues, efforts to nurture environmental awareness can be made through lessons in schools. This study aims at describing the development of a conceptual learning model dubbed EcologicalContextual based for Prosocial (ECOPS) in order to foster prosocial behavior of junior high school students in Cimahi as an alternative for social studies learning. This study is a qualitative descriptive study in which interviews are conducted as means of data collection. The objects of this study involved the social studies teachers of junior high schools in the city of Cimahi. The findings of this study indicate that according to the data obtained, there was no learning model employed in social studies that was based on ecology as an attempt to foster students' prosocial behavior. Therefore, an ecology-based learning model for social studies is needed with the purpose of fostering a sense of prosocial behavior in order to maintain sustainability. The Ecological-Contextual based for Prosocial (ECOPS) model can be used as an alternative for social studies teachers so as to foster students' prosocial behavior.The ECOPS model is an environmental-based social studies learning model that focuses on social interaction to foster the students' caring attitude towards their social environment. Hence, every action and behavior will be by environmental and social sustainability.
\end{abstract}

Keywords: social studies, prosocial, ecology. 


\section{Introduction}

Nature and humans are two inseparable entities. Humans need nature to fulfill their needs and to support their existence. Likewise, nature needs humans to maintain environmental sustainability and harmony. Nature provides diverse resources needed by humans such as water, air, soil, plants, animals, fossil fuels, and others [1]. Therefore, preservation is necessary to maintain the sustainability of the environment so that humans can benefit from nature to meet their needs without overexploiting it. Consequently, all forms of destructive activities must be avoided at all costs. That way, these actions of showing environmental awareness are a form of tolerance which is part of social concern [2].

Unfortunately, as time passes, the harmony between the environment and humans begins to subside. This can be seen from many natural incidents that occurred, one of which was the discovery of various plastic waste as much as 5.9 kilograms inside the stomach of a dead whale in Wakatobi on November 19, 2018. The waste comprised plastic bottles, drinking cups, plastic packaging for instant noodles, bottle caps, plastic sandals, plastic bags, and tarpaulin bags. This phenomenon shows the lack of concern for the environment.

Arne Naess in Mulyana [3], an ecologist, revealed that the current environmental crisis could only be overcome by making fundamental and radical changes in humans' perspective and behavior towards nature. One way to change said behavior is through education, namely school.

Why school? Because school is a place where interactions between teachers and students occur, the transfer of values appears in the learning process. Therefore, if ecological intelligence values are embedded in the learning process, students are expected to have high environmental awareness. Supriatna [4] stated that individuals' ecological intelligence stems from knowledge, understanding, and life skills in harmony with natural sustainability.

Through social studies contextual about ecological issues, efforts to nurture environmental awareness can be made through lessons in schools. Various studies in the field of social studies concerning ecology can be found. Unfortunately, based on the results of in-depth interviews conducted in this study, it was revealed that that there was no learning model in social studies that was based on the environment with the aim to foster students' prosocial behavior. Therefore, an ecology-based learning model for social studies is needed with the purpose of fostering a sense of prosocial behavior in order to maintain sustainability.

This study aims at describing a learning design in social studies dubbed the EcologicalContextual based for Prosocial (ECOPS) model as an alternative in social studies learning for developing ecological material while simultaneously fostering prosocial behavior.

\section{Literature}

\subsection{Social Exchange Theory}

The social, philosophical foundation used in developing the ECOPS model is George C. Homans' social exchange theory, which Peter M. Blau later refined. This theory suggests that social interaction has similarities with economic transactions. However, in terms of social exchange, the 
exchange is the trade of goods for money and a dialogue between the tangible and the intangible. Social exchange theory is the social, philosophical foundation in developing the ECOPS model. In learning social studies with the ECOPS model, social interactions occur between students and teachers and between students and other learning models, in this case, guest teachers, scavengers/garbage collectors, and donation recipients.

\subsection{Social Constructivism}

Vygotsky's theory of social constructivism states that students construct knowledge through social interactions with others. Vygotsky considers the social environment crucial for learning; he suggests that social interactions alter or transform learning experiences [5]. Through Vygotsky's social constructivist paradigm, a student's interactions with the environment can help the learning process run better and will undoubtedly affect the student's learning outcomes. Vygotsky's social constructivism emphasizes that teachers must create many opportunities for students to learn with teachers and peers in constructing shared knowledge [6].

Vygotsky's social constructivism can be used as a basis for developing learning models, especially in social studies. This is because IPS (Ilmu Pengetahuan Sosial - social studies) is a field of study that learns, examines, analyzes social symptoms and problems within society by reviewing various aspects of life or a combination [7]. In other words, social studies learning emphasizes the social environment in which Vygotsky's social constructivist theory applies, constructing knowledge through social interaction with others.

According to Vygotsky's theory of social constructivism, students are encouraged to construct knowledge through interaction with the environment. This is in line with what the researcher will conduct, for in the learning that will be carried out, students are involved in ECOPS learning model that is related to the environment where they live, about concern for the environment and the surrounding community by using a learning media that has been previously designed.

\subsection{Progressivism Theory}

Progressivism is one of the theories in modern educational philosophy which leads to the pragmatism philosophy introduced by William James (1842-1910) and John Dewey (1859-1952). They share the same belief in pragmatism that the human mind is particularly active and seeks to explore, not passive continuously, and does not just accept particular views before empirical proofs [8].

About education in schools, the principle of progressivism can be implemented by making schools a means of revitalization for human progress to facilitate progress-oriented learning. One form of progress in education is using a new learning model, which is a product of creative thinking, in this case, the ECOPS learning model that the researcher has designed. As a result, the learning will be more meaningful for students if the materials provided are contextually relevant to their lives. Contextual Teaching Learning (CTL), which is essentially an actual development of progressivism, designs the ECOPS model. This is related to social studies learning materials regarding environmental care and social care using the environment where students reside. 


\subsection{Ecological Intelligence}

The ecological philosophical foundation used in the ECOPS model is the theory of environmental intelligence by Goleman, which emphasizes that ecological intelligence describes a person's ability to understand the natural system by combining cognitive skills with empathy for all creatures. Furthermore, Goleman [9] listed five things to be developed informing ecological intelligence as a way of affirming the relationship between the intelligence above, namely:

1. Developing empathy for all forms of life

2. Embracing sustainable living with the collective ability to work together to preserve that sustainability

3. I am living in harmony with the environment to understand time, space, and its impact.

4. Anticipating various consequences caused by humans and predicting the possibilities that may occur

5. Understanding how nature sustains life is crucial for students in shaping a community that takes future generations and sustainable living into consideration.

The next theory that serves as the basis for developing the ECOPS model is the theory of ecological evolution proposed by Bronfenbrenner, which states that the environment influences human development as the reciprocal relationship between an individual and the background will shape the individual's behavior [10]. Furthermore, ecological theory views child development from three environmental systems, namely microsystem, ecosystem, and macrosystem [11]

Through social studies learning with the ECOPS model, students are directed to analyze environmental problems around them and use them as a drive-in nurturing social care for others.

\section{Research Methods}

In a qualitative study, data collection is conducted in a natural setting. Data in this study were obtained by means of observation and interviews. Observation means paying attention to phenomena at the site of the study through the five senses, often with instruments or devices, and recording them for scientific purposes [12]. On the other hand, interview is a technique to obtain information from the informants through questions inquired by the interviewer.

In a qualitative study, the instrument of the study is the author him/herself (human instrument). A qualitative study as human interest functions to determine the focus of study, select informants as data sources, collect data, assess data quality, analyze data, interpret data and make conclusions on findings. Data collection methods include observation, interviews and documentation studies. Indepth interviews were conducted with six social studies teachers at a public junior high school in Cimahi.

[13] explains that in the perspective of a qualitative study, the point of view of the problem is holistic in nature (comprehensive, cannot be separated), hence qualitative researchers will not determine their studies solely based on variables of the study, but also on the overall social situation being studied that is based on aspects such as place, actor, and activity that interact synergistically. 


\section{Results and Discussion}

\subsection{Social Studies Learning Materials Regarding Ecology and Prosocial Behavior in Junior High School in Cimahi \\ Based on the data obtained through interviews with 6 social studies teachers at SMP Kota}

Cimahi, $83 \%$ of them stated that a social studies curriculum concerning ecology had not been specifically present in social studies learning. The ecological theme that was not specifically written in the Basic Competencies (KD), added with the absence of the obligation of the curriculum, caused social studies teachers not to further develop ecology-related materials. Social studies material with ecological content is only presented in a global context. It is a similar case with materials related to prosocial behavior. $66 \%$ of the informants said that these materials were not specifically written to be studied, but were given to sociology materials with the theme of social interaction. This was because prosocial behavior appears in the material regarding social interaction. Additionally, from the results of interviews with social studies teachers, it was also found that activities that are based on ecology and prosocial behavior were more encouraged in activities outside of class hours.

Further information regarding ecological learning resources was that $83 \%$ of the respondents claimed that the development of facilities and infrastructure would be carried out if materials concerning ecology and prosocial behavior are developed in social studies learning. This indicates that the use of a learning model that is based on ecology and prosocial behavior have the potential to get supports from school, one of which is in form of the provision of facilities and infrastructure.

In addition to the information mentioned above, it was obtained that $100 \%$ of respondents claimed that they had never used a learning model in social studies learning that is based on ecological intelligence in order to foster prosocial behavior. 33\% of respondents admitted that they had used an ecologically based learning model, but not for the purpose of fostering prosocial behavior. On the other hand, $50 \%$ of respondents claimed to have used learning models that aim to foster prosocial behavior although they were not based on ecology.

Therefore, this study aims at providing an alternative social studies learning based on two things at once, namely ecology and prosocial behavior, in which ecology is used as learning material with the aim of fostering students' prosocial behavior. The model offered is called EcologicalContextual based for Prosocial (ECOPS) model which has philosophical foundations in educational, ecological and prosocial theories.

\subsection{Ecological Contextual Based for Prosocial (ECOPS) Model Syntax}

Syntax in the ECOPS model is divided into five phases: stimulation, response, knowledge construction-confirmation, analysis, and application communication. The initial model of the syntax of Ecological Contextual Based for Prosocial (ECOPS) is shown below: 


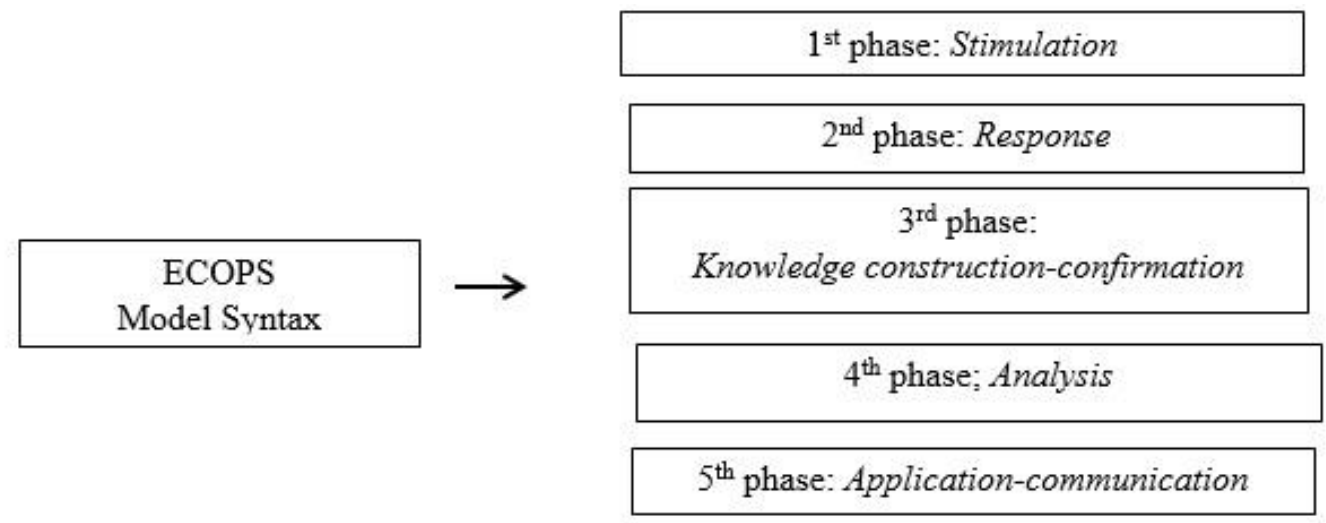

Fig. 1. Ecological-Contextual based for Prosocial (ECOPS) Model Syntax

Students are given a stimulus at the stimulation stage, either in the form of a video or a learning model (modeling) that is related to the environment presented by the teacher in the classroom. The provision of this stimulus aims to trigger students' critical thinking about the learning materials that will be studied. At the response stage, students are allowed to express their opinions regarding the given stimulus. This stage can reflect the students' reaction towards the given stimulus. At the knowledge construction-confirmation stage, the teacher explains the learning materials. This is done to avoid misunderstanding the concept of learning objectives and students' perceptions. At this stage, the teacher accommodates the students with opportunities to ask questions. By this, there a lively discussion between teachers and students is conducted. At the analysis stage, students are given exercises, either in the form of questions or a project assigned to measure the extent of their comprehension of the learning materials. At this application-communication stage, the students express their views on the questions/projects/problems presented. This is done to communicate the final actions that students will take in dealing with the social problems that have been introduced in the form of questions and projects. Several methods are employed in the ECOPS model, namely lecture, question and answer session, discussion, and cooperative learning. As for the assessment, the ECOPS model assesses several aspects, namely attitude, knowledge, and skills. Evaluation of attitude is carried out using a checklist with adjusted categories for each meeting. The knowledge aspect is measured using written and oral tests and assignments; meanwhile, the element of skills is measured by assessing the students' performances, including students' participation throughout the learning process.

\section{Conclusion}

Social studies learning as an attempt to foster students' prosocial behavior by means of caring for the environment has not been optimally developed in schools. Normally, the focus of social studies only relies on one concern without combining the concerns; ecological and prosocial. Based on the obtained data, it is evident that ecological competence and prosocial behavior have not become the main focus in social studies learning in junior high schools, resulting in the absence of 
a learning model that is specifically used during learning that is related to ecology and prosocial behavior. However, if we take a closer look, materials related to ecology and prosocial behavior can be used as a special topic by adapting or developing it based on the existing Basic Competencies (KD) of Social Studies subject in junior high school. To make these ecological and prosocial materials more meaningful, the selection of learning models is key. In addition, the selection of a suitable learning model can enable easier process in achieving learning objectives. Therefore, the ECOPS model can be used as an alternative in social studies learning in relation to ecology and prosocial behavior. The ECOPS model is an environmental-based social studies learning model that focuses on social interaction to foster the students' caring attitude towards their social environment. Hence, every action and behavior will be by environmental and social sustainability.

\section{References}

[1] M. Desfandi, "Efektivitas Program Adiwiyata Dalam Upaya Membangun Literasi Ekologis Peserta Didik," Universitas Pendidikan Indonesia, 2016.

[2] R. Tumanggor and Dkk, Ilmu Sosial dan Budaya Dasar. jakarta: PRENA-DAMEDIA GROUP, 2014.

[3] R. Mulyana, "Penanaman Etika Lingkungan Melalui Sekolah Perduli dan Berbudaya Lingkungan," J. Tabularas PPS UNIMED, vol. 6, no. 2, p. 175, 2009.

[4] N. Supriatna, "Prosa Dari Praha," Bandung: Remaja Rosdakarya, 2018, p. 24.

[5] D. . Schunk, Learning Theories an Educational Perspective Teori-teori Pembelajaran: Perspektif Pendidikan, Edisi keen. Yogyakarta: Pustaka Belajar, 2010.

[6] J. . Santrock, Psikologi Pendidikan, Edisi Kedu. Jakarta: Prenada Media Group., 2010

[7] Sardjiyo and dkk, Pendidikan IPS di SD. Jakarta: Universitas Terbuka, 2007.

[8] U. Sadullah, Pengantar Filsafat Pendidikan. Bandung: Alfabeta, 2003.

[9] D. Goleman, L. Bennet, and Z. Barlow, Eco Literacy. San Fransisco: Jossey-Bass Published., 2021.

[10] Mujahidah, "Implementasi Teori Ekologi Bronfenbrenner dalam Membangun Pendidikan Karakter yang Berkualitas," Lentera, vol. 17, no. 2, p. 173, 2015.

[11] P. A. Bronfenbrenner, U., \& Morris, The ecology of developmental processes, In W. Damo. John Wiley \& Sons Inc., 1998.

[12] J. . Creswell, Penelitian Kualitatif \& Desain Riset. Yogyakarta: Pustaka Belajar, 2013.

[13] Sugiyono, Metode Penelitian Kuantitaitf, Kualitatif, dan Kombinasi (Mixed Methods). Bandung: Alfabeta, 2015. 